症例

\title{
チフス性疾患との鑑別に難渋したが地方衛生研究所との連携により 診断に至った発疹熱
}

\author{
${ }^{12}$ 川崎市立川崎病院感染症内科, ${ }^{27}$ 順天堂大学医学部総合診療科, ${ }^{37}$ 川崎市健康安全研究所 \\ 細田 智弘 ${ }^{122}$ 三㟝 貴子 ${ }^{3)}$ 清水 英明 ${ }^{3)}$ \\ 岡部 信彦 ${ }^{3)}$ 坂本 光男 ${ }^{1)}$
}

(平成 29 年 8 月 22 日受付)

(平成 30 年 3 月 6 日受理)

Key words : murine typhus, typhoid fever, Rickettia typhi

\section{緒言}

発疹熱の原因微生物である Rickettia typhi は, 自然 界ではべクターであるノミとリザーバーであるネズミ や猫の間で感染が広がっている ${ }^{1)}$.多くのリケッチア 感染症のベクターであるダニの咬傷と異なり，ノミの 噛み口は見つからないことが多く, 咬傷部位のアレル ギー反応である痂皮の形成もない2．発疹熱の主な症 状は発熱・頭痛・皮疹だが ${ }^{3)}$, いずれも非特異的で, 東 南アジアなどの流行地では, 類似の症状を呈するデン グ熱やチフス性疾患（腸チフス・パラチフス）の発生 も多いため鑑別に難渋する. 確定診断は血清学的検査 や核酸増幅検査で行うが ${ }^{1}$, いずれも一般の医療機関 では実施できず，地方衛生研究所や国立感染症研究所 等の研究機関への依頼が必要である ${ }^{4)}$. したがって積 極的に本疾患を鑑別しない限り，血液培養等で偶発的 に診断されることはない. テトラサイクリン系抗菌薬 が有効であるが，無治療で自然治癒することも多いた め, 診断や治療を䛊っても気づかないこともある11. 以 上から発疹熱は診断されにくく, さらに本邦では感染 症の予防及び感染症の患者に対する医療に関する法律 (感染症法)による届出対象疾患ではないため, 正確 な発生動向は不明である.

\section{症例}

患者 : 19 歳, フィリピン人女性.

主訴: 発熱, 頭痛.

既往歴：なし.

アレルギー：なし.

生活歴：フィリピンで出生し， 6 年前に来日し関東

別刷請求先：（２10-0013）神奈川県川崎市川崎区新川通 $12-1$

川崎市立川崎病院感染症内科細田 智弘
地方で母と 2 人暮らし. 契煙歴や飲酒歴はなく, 職業 は飲食店でアルバイト。

ワクチン接種歴 : 小児期に麻疹・風疹のワクチン接 種あり (本人の記憶).

家族歴：6 年前に弟が腸チフスに罹患した.

現病歴：2016 年. 4 週間前にフィリピン・ミンダナ オ島の実家に帰省した．6月で雨季だった．現地で生 水の摂取があった。実家では犬を飼育しており，付近 で猫やネズミも頻回に目撃した。頻回に蚊に刺された が, ダニに噛まれたことはなかった。 山林河川の散策 歴はなく, 公営のプールで数回泳いだ。 1 週間前に日 本に帰国した。 3 日前から発熱と頭痛を認め, 近医を 受診した. セフカペン・ピボキシル等を処方され内服 したが, 症状は改善せず精査・加療目的で当院に紹介, 入院した. 前医から地方衛生研究所である川崎市健康 安全研究所 (以下健安研) に本患者の検査依頼があり, 当院初診時には血液検体におけるデングウイルス・チ クングニアウイルス・ジカウイルスの PCR 検査の陰 性が判明していた。

入院時現症 : 意識清明, 体温 $39.7^{\circ} \mathrm{C}$, 心拍数 104 回/ 分, 血圧 98/60mmHg, 呼吸数 15 回/分, $\mathrm{SpO}_{2} \quad 99 \%$ (室内気)。頭頸部は眼球結膜や頸部リンパ節含めて異 常はなかった．心音・呼吸音に異常はなかった．腹部 は平坦・軟だが, 右季肋部にごく軽度の圧痛を認めた。 四肢には両側下腿・大腿に軽度の自発痛・把握痛を認 めた。皮膚は体幹・四肢に薄い紅斑を認めた（Fig. 1).

入院時検査所見 (Table 1)：血小板減少, FDP ·肝 胆道系酵素・ CRP の上昇を認めた。 未梢血塗抹標本 ギムザ染色ではマラリア原虫はみられなかった。 なお 入院第 3 病日の血液像では好酸球は $0 \%$ であった. 胸 
部 X 線検查で肺野の浸潤影などの異常はなかった. 腹 部エコーで肝膿瘍や肝脾腫等はみられず，下肢血管エ コーで深部静脈血栓はみられなかった.

経過（Fig. 2)：東南アジアへの渡航歴, 生水摂取 歴, 比較的徐脈と非特異的な症状からチフス性疾患(腸 チフス・パラチフス）と初期診断し血液培養を 2 セッ 卜採取した．全身状態は比較的良好であり，入院時に 経口第 3 世代セフェム系抗菌薬を内服していたため, 血液培養からの起因菌の検出感度を上げるために抗菌 薬を中止し，48 時間後に血液培養を再検した後に抗 菌薬治療を開始する方針とした。鑑別にレプトスピラ 症や各ウイルス性疾患等を挙げた。麻疹については, 同時期にフィリピンおよび日本国内で流行しておら ず，比較的全身状態が良好で皮疹の分布が非典型的で あったが, 麻疹・風疹のワクチン接種歴が本人の記憶 によるものであるため, 修飾麻疹の可能性も考虑し入 院時は陰圧管理を行った，HIV を含めた各種ウイル

Fig. 1 Pale rash on the left forearm

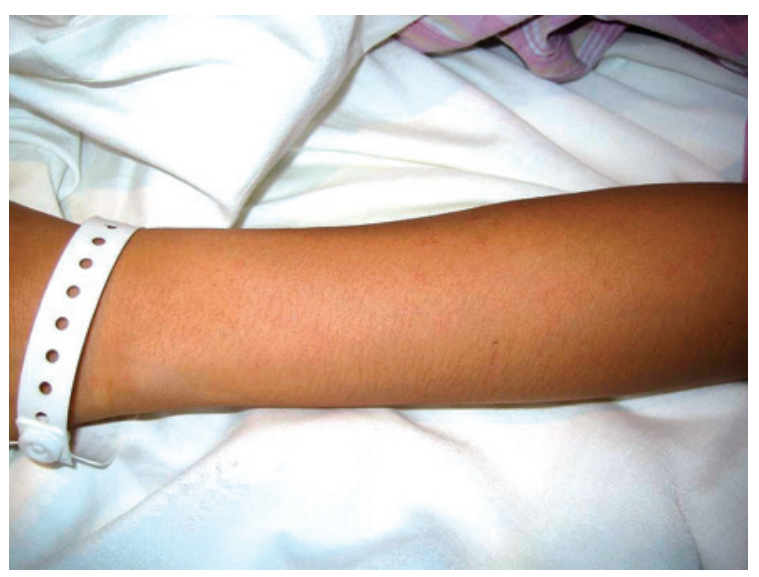

又抗原あるいは抗体の検索や血清抗赤痢アメーバ抗体 はいずれも発熱の原因として否定的な結果であった (Table 1)，骨髄穿刺や腰椎穿刺は同意が得られず実 施できなかった，入院時の血液培養は陰性であり，入 院 3 日目に血液培養をさらに 2 七ッ卜採取した後, チ フス性疾患に対する経験的治療として ceftriaxone （CTRX）2g/日の投与を開始した。皮疹, 乾性咳嗽, 血小板減少は徐々に改善したが, 発熱, 頭痛, 筋肉痛 の改善には乏しかった，入院時及び入院 3 日目の血液 培養は, 入院 6 日目にも陰性のままでありリケッチア 感染症を疑った，一方でCTRXによる治療反応が至 しかったため,レプトスピラ症としては非典型的と考 えた。 入院 3 日目（第 6 病日）に採取した血漿・末梢 血単核球・血清を用いて, 健安研でリケッチア群の PCR 検查を実施した。まずリケッチア属を広く検出 できる $17 \mathrm{kDa}$ 蛋白抗原遺伝子を標的とするプライ マー $(\mathrm{R} 1 / \mathrm{R} 2)^{5)}$ を用いて $1 \mathrm{st} \mathrm{PCR}$ を行い, その後 $1 \mathrm{st}$ PCR 産物をテンプレートとして, 発疹熱 (Rty $2 \mathrm{~F} /$ Rty $3 R)$, 発疹チフス $(\text { Rpro } 2 \mathrm{~F} / \text { Rpro 3R })^{6)}$, リケッチア 属共通 inner プライマー $(\operatorname{Rr} 17.61 \mathrm{p} / \mathrm{Rr} 17.492 \mathrm{n})^{7)}$ を用 いて nested PCR を行った。 入院 9 日目に頭痛や筋肉 痛が増悪した. CTRX の効果が不十分であると考え, 同日昼から抗菌薬を azithromycin 500mg/日（経口） に変更した．数時間後には入院後初めて $37^{\circ} \mathrm{C}$ 前後に 解熱した，同日夕方に，健安研での PCR 検查で R. typhi が陽性であると判明し (Fig. 3), minocycline 200 $\mathrm{mg}$ /日（経口）に変更した。翌日には頭痛や筋肉痛の 改善が見られ，発熱もみられず，入院 11 日目に退院 した。後日，国立感染症研究所に発症第 3 病日と発症 第 30 病日のペア血清を用いて間接蛍光抗体法による 抗体価の測定を依頼したところ，R. typhi に対して有

Table 1 Laboratory data

\begin{tabular}{|c|c|c|c|c|c|}
\hline Hematology & & Biochem & & Infection & \\
\hline WBC & $6,050 / \mu \mathrm{L}$ & Alb & $4.1 \mathrm{~g} / \mathrm{dL}$ & *Dengue PCR & $(-)$ \\
\hline $\mathrm{RBC}$ & $501 \times 10^{4} / \mu \mathrm{L}$ & T-cho & $125 \mathrm{mg} / \mathrm{dL}$ & *Chikungunya PCR & $(-)$ \\
\hline $\mathrm{Hb}$ & $15.0 \mathrm{~g} / \mathrm{dL}$ & T-Bil & $0.5 \mathrm{mg} / \mathrm{dL}$ & *Zika PCR & $(-)$ \\
\hline $\mathrm{Ht}$ & $41.7 \%$ & AST & 137 IU/L & Plasmodium species for peripheral blood smear & $(-)$ \\
\hline PLT & $4.1 \times 10^{4} / \mu \mathrm{L}$ & ALT & $100 \mathrm{IU} / \mathrm{L}$ & HIV antigen/antibody & $(-)$ \\
\hline Coagulation & & $\mathrm{LDH}$ & $507 \mathrm{IU} / \mathrm{L}$ & $\mathrm{EBV} \operatorname{lgM} / \operatorname{lgG} / \mathrm{EBNA}$ & $(-) /(+) /(-)$ \\
\hline PT-INR & 1.06 & ALP & $213 \mathrm{IU} / \mathrm{L}$ & CMV $\operatorname{lgM} / \operatorname{lgG}$ & $(-) /(+)$ \\
\hline APTT & $22.6 \mathrm{sec}$ & BUN & $5 \mathrm{mg} / \mathrm{dL}$ & Measles $\lg \mathrm{M} / \operatorname{lgG}$ & $(-) /(+)$ \\
\hline Fib & $408.0 \mathrm{mg} / \mathrm{dL}$ & $\mathrm{Cr}$ & $0.6 \mathrm{mg} / \mathrm{dL}$ & Rubella $\operatorname{lgM} / \operatorname{lgG}$ & $(-) /(+)$ \\
\hline FDP & $15.3 \mu \mathrm{g} / \mathrm{mL}$ & $\mathrm{Na}$ & $135 \mathrm{mEq} / \mathrm{L}$ & Parvovirus B19 lgM & $(-)$ \\
\hline Urinary & & $\mathrm{K}$ & $3.7 \mathrm{mEq} / \mathrm{L}$ & Hepatitis A lgM & $(-)$ \\
\hline $\mathrm{pH}$ & 6.0 & $\mathrm{Cl}$ & $98 \mathrm{mEq} / \mathrm{L}$ & Hepatitis B surface antigen & $(-)$ \\
\hline Protein & $(+)$ & $\mathrm{CK}$ & $69 \mathrm{IU} / \mathrm{L}$ & Hepatitis $C$ antibody & $(-)$ \\
\hline Occult blood & $(+)$ & Lac & $2.0 \mathrm{mmol} / \mathrm{L}$ & RPR/TPHA & $(-) /(-)$ \\
\hline WBC & $( \pm)$ & CRP & $5.24 \mathrm{mg} / \mathrm{dL}$ & Entamoeba histolytica $\lg G$ & $(-)$ \\
\hline
\end{tabular}

EBV; Epstein-Barr virus, VCA; viral capsid antigen, EBNA; Epstein-Barr virus nuclear antigen, CMV; cytomegalovirus

*Performed in Kawasaki City Institute for Public Health 
Fig. 2 Clinical course

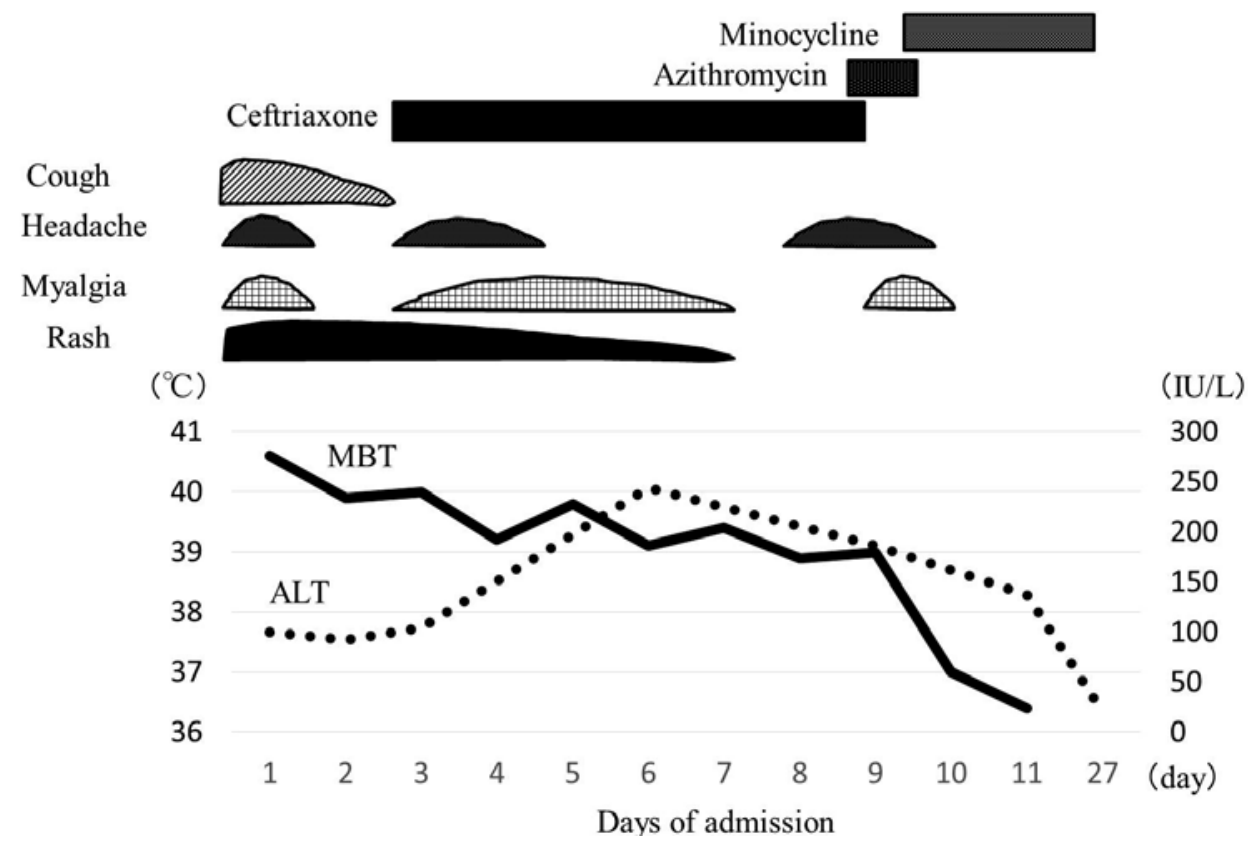

Fig. 3 Result of polymerase chain reaction test

The white arrowhead indicates a 434-bp DNA fragment; amplification of the Rickettia species common antigen. The white arrow indicates a 267-bp DNA fragment; amplification of the Rickettia typhi specific antigen.

PBMC; peripheral blood mononuclear cell NC; negative control
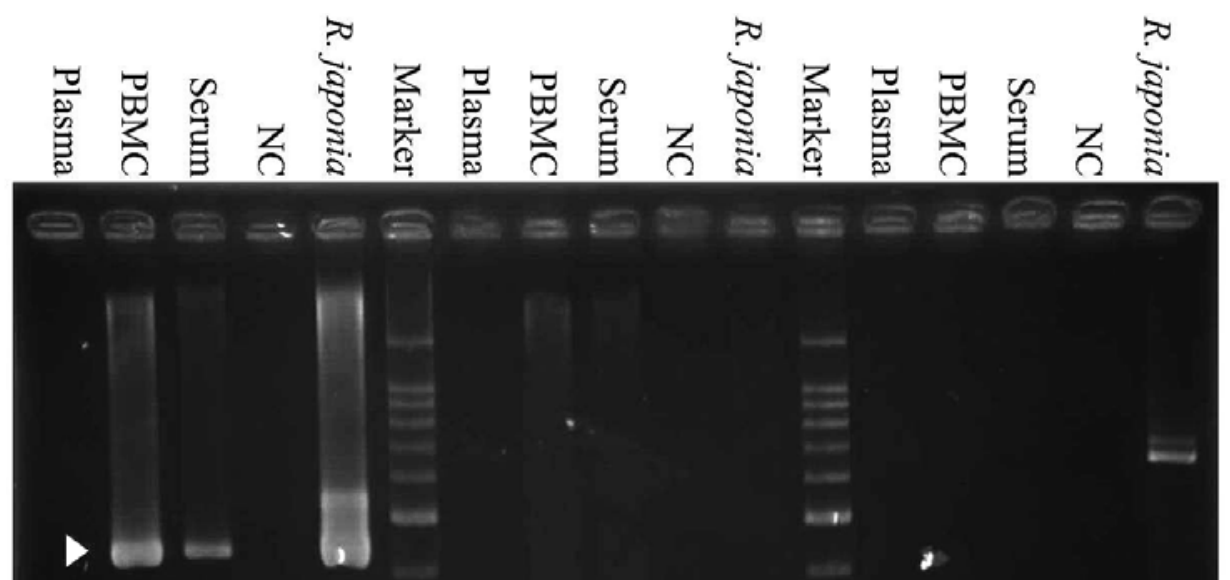

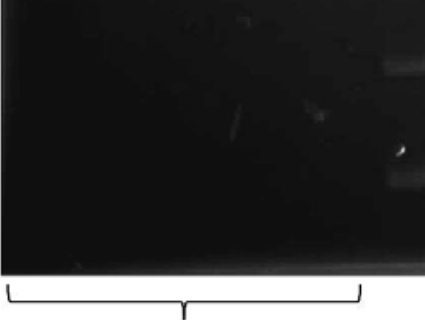

Rickettia species common antigen (17kDa) (Rr17.61p/Rr17.492n)
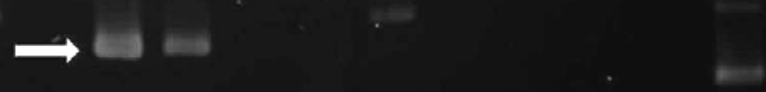

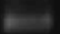

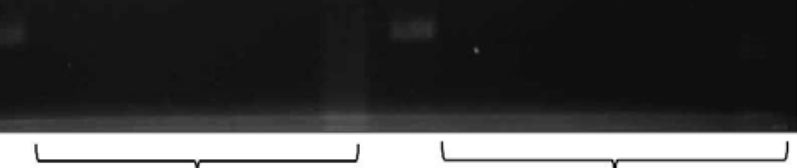

R. typhi (Rty2F/Rty3R) R. prowaseki (Rpro2F /Rpro3R)

PBMC; peripheral blood mononuclear cell NC; negative control 
Table 2 Published recent imported cases of murine typhus

\begin{tabular}{|c|c|c|c|c|c|c|c|c|c|c|c|c|}
\hline Case & $\begin{array}{l}\text { Report } \\
\text { year }\end{array}$ & Age & $\begin{array}{l}\text { Gen- } \\
\text { der }\end{array}$ & Race & $\begin{array}{l}\text { Travel } \\
\text { area }\end{array}$ & Rash & $\begin{array}{l}\text { Respiratory } \\
\text { findings }\end{array}$ & Initial diagnosis & $\begin{array}{l}\text { Inspection } \\
\text { station }\end{array}$ & Diagnosis & Therapy & $\begin{array}{l}\text { Refer- } \\
\text { ence }\end{array}$ \\
\hline 1 & 2006 & 54 & M & $\mathrm{N} / \mathrm{A}$ & Vietnam & $\begin{array}{l}\text { Trunk, } \\
\text { extremities }\end{array}$ & $\mathrm{N} / \mathrm{A}$ & N/A & NIID & $\begin{array}{l}\text { WF, IFA, } \\
\text { ※PR }(-)\end{array}$ & Empirical & 8 \\
\hline 2 & 2009 & 22 & $\mathrm{~F}$ & Japanese & China & - & $\mathrm{N} / \mathrm{A}$ & $\mathrm{N} / \mathrm{A}$ & PHI (Tokyo) & $\begin{array}{l}\text { WF, PCR, } \\
\text { IFA }\end{array}$ & Empirical & 9 \\
\hline 3 & 2009 & 23 & $\mathrm{M}$ & Japanese & Indonesia & $\begin{array}{l}\text { Face, trunk, } \\
\text { extremities }\end{array}$ & $\mathrm{N} / \mathrm{A}$ & $\begin{array}{l}\text { Typhoid fever, } \\
\text { leptospirosis }\end{array}$ & NIID & PCR & Empirical & 7,10 \\
\hline 4 & 2009 & 23 & M & $\mathrm{N} / \mathrm{A}$ & Indonesia & Chest, arm & - & Dengue fever & NIID & PCR, IFA & None & 7,11 \\
\hline 5 & 2013 & 56 & M & Japanese & Thailand & Chest & $\begin{array}{l}\text { Tachypnea, } \\
\text { ARDS, } \\
\text { abnormal } \\
\text { chest X-ray }\end{array}$ & $\begin{array}{l}\text { Dengue shock } \\
\text { syndrome, } \\
\text { epidemic typhus, } \\
\text { septic shock due to } \\
\text { bacterial infection }\end{array}$ & NIID & PCR & Empirical & 12 \\
\hline 6 & 2014 & 20 & M & Japanese & Indonesia & - & Cough & Typhoid fever & PHl (Tokyo) & PCR & Empirical & 13 \\
\hline 7 & 2015 & 43 & M & $\mathrm{N} / \mathrm{A}$ & Indonesia & Trunk & $\begin{array}{l}\text { Abnormal } \\
\text { chest X-ray }\end{array}$ & $\mathrm{N} / \mathrm{A}$ & $\mathrm{N} / \mathrm{A}$ & IFA & Empirical & 14 \\
\hline $\begin{array}{l}\text { This } \\
\text { case }\end{array}$ & 2017 & 19 & $\mathrm{~F}$ & Philippines & Philippines & Trunk, arm & Cough & Typhoid fever & $\begin{array}{l}\text { PHI (Kawasaki), } \\
\text { NIID }\end{array}$ & PCR, IFA & Definitive & - \\
\hline
\end{tabular}

ARDS; acute respiratory distress syndrome, WF; weill-felix reaction, IFA; immunofluorescent assay

意な抗体価の上昇（IgM 160/>640, IgG>640）が認 められた。 なお R. prowazekii に対する抗体上昇（IgM 80/320，IgG 80）も認められたが，交叉反応と考えら れた。

\section{考察}

本例は，チフス性疾患との鑑別に難渋したが，地方 衛生研究所との連携によって, 経験的治療を開始する 前に早期に診断できた発疹熱の 1 例である。2000 年 以降の国内の発疹熱の輸入例は 7 例報告されている が，経験的な治療介入の前に診断を行うことができた 症例の報告は本例のみである $(\text { Table } 2)^{\text {7) 14) }}$.

本例でチフス性疾患の除外に難渋した理由に, チフ ス性疾患の血液培養の感度の低さや, CTRX で治療 した場合の治療反応の遅さがある ${ }^{15)}$ ，発疹熱の症状は 非特異的で，かつ一般医療機関での確定診断が難しい ため，国内の既報でも他疾患の治療を行いながら本疾 患を鑑別に挙げている症例がみられる（Table 2)。発 疹熱の流行地であっても，本例と同様に発疹熱とチフ ス性疾患の鑑別は難渋し，発疹熱の 4 割程度がチフス 性疾患と初期診断されているという報告もある ${ }^{16)}$. 両 者を比較した報告では咳嗽などの呼吸器症状がチフス 性疾患では有意に少ないとされている ${ }^{17}$. またチフス 性疾患の皮疹は体幹のごく限られた部位で，かつ $5 \%$ 未満と極めてまれにしか見られないが15)，発疹熱の皮 疹はしばしば身幹から四肢に広がる ${ }^{3116)}$ 。これらの報 告によると, 発疹熱の呼吸器症状は咳嗽が $66 \%$, 息 切れが $32 \%$ で ${ }^{17)}$ ，四肢への皮疹は上肢が $37 \%$ ，下肢 が $45 \%$ と ${ }^{16)}$ ，いずれも発疹熱で高率に合併する所見 とは言い難いが，チフス性疾患では稀である。本例の ようにチフス性疾患と暫定診断をした症例にこれらの 所見が見られた場合には，リケッチア感染症などの他 の鑑別疾患を念頭に置きながら診療にあたるきっかけ
になると考える。国内の発疹熱の既報でも，一部の症 例には咳嗽や呼吸不全の合併や，四肢に広がる皮疹の 合併が見られ，本例でも初診時に乾性咳嗽や四肢に広 がる皮疹がみられた（Table 2)。チフス性疾患の初期 診断に対して疑問を持つことができれば，より早い段 階でリケッチア感染症を鑑別に挙げ，検査を行うこと ができる。

本例は経過を通じて地方衛生研究所と連携を図り, 確定診断後に治療介入を行うことができた．前述のよ うに発疹熱などのリケッチア感染症は診断に難渋す る。そのため渡航者の発熱に対するアプローチに関す る最近の総説では, 東南アジアからの帰国者の皮疹を 伴う発熱では，マラリアやデング熱を除外した上でリ ケッチア感染症などを想定した経験的治療を行うこと が推奨されている ${ }^{18)}$. 確かに発疹熱は一般医療機関で の確定診断が困難で，研究機関における検査でも，間 接蛍光抗体法には迅速性の, PCR 検査には検査費用 の問題があり ${ }^{1)}$, 確定診断よりも経験的治療を優先せ ざるを得ないこともある。しかし抗菌薬適正使用の観 点からは, 頻度が低く, かつ比較的軽症な発疹熱に対 して，疑似症例まで含めた全例に経験的治療を行うべ きか疑問が残る. また未診断の症例が多数存在するこ とで疫学的な頻度が不明となることも危惧される。一 般に地方衛生研究所等の行政検査機関における検査 は, 結果の報告に長時間を要すると考えられがちであ る.しかしリケッチア感染症の PCR 検査では共通抗 原の検出と特異的抗原の検出の 2 段階で行い, 所要時 間は合計で 6 時間程度である ${ }^{5) 6}$. 本例のリケッチア群 の PCR の検査結果は週末を含めて依頼後 3 日で報告 を受けることができた。発疹熱は感染症法における届 出対象疾患ではないため, 行政検体としての検査を 行っていないが, 本例は発熱や頭痛など臨床所見の改 
善に乏しかったため, 地方衛生研究所でも重症例と判 断し, 積極的疫学調查の一環としてリケッチア群の PCR を実施した. 全ての地方衛生研究所で検査が可 能であるとは限らないが, 本例では臨床医からの病歴 や経過の報告によって, 検査結果が臨床判断に与える 影響を臨床医と行政機関が共有しつつ, 円滑な検査の 実施と結果の報告を行うことができたと考える.

発疹熱とチフス性疾患はしばしば鑑別に難渋する が, 呼吸器症状や四肢への皮疹の広がりがみられる場 合は, チフス性疾患よりも発疹熱を疑って研究機関へ の検査依頼を考慮する。一般医療機関の臨床医は，患 者の臨床情報の収集を含めて, 地方衛生研究所と連携 して診療に当たることが重要である.

謝辞: 本例の診断に際して重要な検査である間接蛍 光抗体法を行って頂きました, 国立感染症研究所ウイ ルス第 1 部安藤秀二先生に深謝いたします。

本論文の要旨は第 91 回日本感染症学会総会・学術 講演会（2017 年 4 月，東京）で発表した。

利益相反自己申告 : 申告すべきものなし

$$
\text { 文献 }
$$

1) Aung AK, Spelman DW, Murray RJ, Graves $\mathrm{S}$ : Rickettsial infections in Southeast Asia : implications for local populace and febrile returned travelers. Am J Trop Med Hyg 2014; 91 : $451-60$.

2) Gordon CC, Alimuddin IZ : Manson's Tropical Diseases (22nd edition). Elsevier Saunders, Philadelphia, 2009 ; p. 885-902.

3) Civen R, Ngo V: Murine typhus:an unrecognized suburban vectorborne disease. Clin Infect Dis $2008 ; 46: 913-8$.

4) 厚生労働省 発疹熱の輸入感染症例の発生につ いて http://www.mhlw.go.jp/bunya/kenkou/ke kkaku-kansenshou24/index.html.

5) 国立感染症研究所（レファレンス委員会）・地方 衛生研究所全国協議会 リケッチア感染症診断マ ニュアル，平成 13 年.

6) 国立感染症研究所（レファレンス委員会）・地方 衛生研究所全国協議会 発疹チフス群リケッチ ア診断マニュアル, 平成 14 年.

7) Takeshita N, Imoto K, Ando S, Yanagisawa K, Ohji G, Kato Y, et al. : Murine typhus in two travelers returning from Bali, Indonesia: an un- derdiagnosed disease. J Travel Med 2010; 17 : 356 - 8 .

8) Azuma M, Nishioka Y, Ogawa M, Takasaki T, Sone S, Uchiyama $\mathrm{T}$ : Murine typhus from Vietnam, imported into Japan. Emerg Infect Dis $2006 ; 12: 1466$-8.

9）小林泰一郎, 中村 $[$ 内山 $]$ ふく, 古宮伸洋, 大 西健児, 新開敬行: 中国海南島で感染した発疹 熱の 1 例. 感染症誌 $2009 ; 83: 747$-8.

10）竹下 望, 柳沢邦雄, 加藤康幸, 金川修造, 坂 田明子, 安藤秀二, 他：インドネシアからの輸 入症例と考えられる急性腎不全を伴った発疹熱 の 1 例. 感染症誌 $2009 ; 83: 748$.

11）井本一也, 大路 剛, 山本舜悟, 細川直登, 岸 本寿男, 安藤秀二, 他: 当院で経験した発疹熱 (Murine Typhus)の症例. 感染症誌 2009；83： 748.

12) Sakamoto N, Nakamura-Uchiyama F, Kobayashi K, Takasaki T, Ogasawara Y, Ando S, et al. : Severe murine typhus with shock and acute respiratory failure in a Japanese traveler after returning from Thailand. J Travel Med 2013 ; $20: 50-3$.

13）加藤博史, 柳澤如樹, 関谷紀貴, 菅沼明彦, 今 村顕史, 味澤 篤: インドネシア渡航後に発症 した発疹熱の 1 例. 感染症誌 $2014 ; 88: 166$ 一 70.

14) Yoshimura Y, Sakamoto Y, Kwangyeol L, Amano Y, Tachikawa N : Round Pneumonia With Murine Typhus After Travel to Indonesia. J Travel Med $2015 ; 22: 353-4$.

15) Benette JE, Dolin R, Blaser ML : Mandell, Douglas, and Bennett's Principles and Practice of Infectious Diseases (8th edition). ElsevierSaunders, Philadelphia, 2015 ; p. 1270-82.

16) Dumler JS, Taylor JP, Walker DH : Clinical and laboratory features of murine typhus in south Texas, 1980 through 1987. JAMA $1991 ; 266$ : 1365-70.

17) Zimmerman MD, Murdoch DR, Rozmajzl PJ, Basnyat B, Woods CW, Richards AL, et al. : Murine typhus and febrile illness, Nepal. Emerg Infect Dis $2008 ; 14: 1656$-9.

18) Thwaites GE, Day NP : Approach to Fever in the Returning Traveler. N Engl J Med 2017 ; $376: 548-60$. 
Murine Typhus which was Difficult to Distinguish from Typhoid Fever; a Case Report and an Effective Collaboration with a Local Institute of Public Health

Tomohiro HOSODA ${ }^{12)}$, Takako MISAKI ${ }^{3)}$, Hideaki SHIMIZU ${ }^{3)}$, Nobuhiko OKABE ${ }^{3)}$ \& Mitsuo SAKAMOTO ${ }^{1)}$ ${ }^{1}$ Department of Infectious Disease, Kawasaki Municipal Kawasaki Hospital,

${ }^{2}$ Department of General Medicine, Juntendo University School of Medicine,

${ }^{31}$ Kawasaki City Institute for Public Health

Herein we present the case of a 19-year-old healthy Filipino woman with a 4-day history of fever and headache, who upon admission had a dry cough and rashes distributed on her trunk and proximal limbs. The patient had recently traveled to the Philippines, 1-4 weeks prior to admission, where she had been in close contact with cats and rodents. Laboratory tests showed thrombocytopenia, and elevation of liver enzyme and C-reactive protein levels. Subsequent polymerase chain reaction (PCR) tests for Dengue, Chikungunya, and Zika virus, respectively, and Giemsa-stained blood smear for malaria were negative. Her chest Xray was normal. Our initial diagnosis was typhoid fever. However, even after administering ceftriaxone, the patient's fever and headache remained unimproved. A PCR analysis for Rickettsia species was then performed on day 6 of hospitalization, which revealed the presence of Rickettsia typhi. Therefore, the patient was diagnosed as having murine typhus, and minocycline treatment was started on day 9 of hospitalization. The patient's clinical symptoms then continued to improve until discharge on day 11 of hospitalization. Diagnosing murine typhus is difficult in clinical practice because of the non-specific symptoms. Respiratory symptoms and rashes spreading to the extremities will be indicators in distinguishing murine typhus from typhoid fever.

〔J.J.A. Inf. D. 92 : 391 396, 2018〕 